\title{
Study of Physical Property of Kodo (Paspalum scrobiculatum L.) Millet
}

\author{
Shalini Chaturvedi ${ }^{1}$ *, Atul Kumar Shrivastava ${ }^{1}$, Ganesh Kumar Koutu ${ }^{1}$, \\ Shiv Ramakrishnan ${ }^{2}$ and Sanjay Singh ${ }^{1}$
}

${ }^{1}$ Department of Farm Machinery and Power Engineering, ${ }^{2}$ Department of Plant Physiology and Genetics, College of Agricultural Engineering, JNKVV, Jabalpur, M.P., India

*Corresponding author

\section{A B S T R A C T}

\begin{tabular}{|l|}
\hline Ke y w o r d s \\
Kodo millet, \\
Moisture content, \\
Physical property, \\
Improved variety
\end{tabular}

\section{Introduction}

The word "Millets" is used to represent many small-grained cereals. Millets crops comprise of pearl millets, sorghum, finger millet \&small millets namely foxtail millets (Kagani), Kodo millets (Kodo), proso millets (Cheena), banyard millets (Sawan) and little millets (Kutki). Millets are one of the oldest cultivated food grains known to humans and have been a stable food in Northern Africa for thousand years and was a stable food in China and India prior to popularity of fine cereals like rice and wheat. These crops have a long history of cultivation of more than 5000 years and grown in many states. The area of small millets in India recorded 682.33 thousand ha, with production of 429.9 thousand and yield 
630.00Kg/ha. Madhya Pradesh covers 33.4percent (227.7 thousand ha) of area and contributes 26.6 percent (114.5 thousand) of production with the average yield of only 503 $\mathrm{Kg} / \mathrm{ha}$ small millets in the country (Directorate of Economics and Statistics (2015).

Kodo grains contain protein $(8.35 \%)$, fat (1.45\%), carbohydrates $(65.65 \%)$ and ash $(2.95 \%)$. It may be considers as nutri-cereal little millet exhibit diversified use as food, feed and fodder. The grain compares well with other cereals. It is a fair source of protein (7070 to $16.50 \%)$, fat $(2.45$ to $9.04 \%)$, carbohydrates (62.50 to $76.30 \%$ ), an excellent source of dietary fibre(15.90 to $18.10 \%$ ) with good amount of soluble (3.15 to $5.70 \%$ ) and insoluble $(10.20$ to $14.95 \%)$ fractions (Kulkarni et al., 1992, Hadimani and Malleshi, 1993 and Itagi, 2003).

Designing of machinery requires through understanding of essential engineering properties of agricultural material. Such basic information is of great importance for not only to engineers but also to food scientist and processor and other scientist who may exploit these properties and find new uses (Mohsenin, 1986). Knowledge of physical properties and their dependence on the moisture content are useful for the design and development of machine. These properties are used in analyzing and determining the efficiency of the machine and operation or process as well as determine quality or studying the behaviour of the product during testing of machine. Basic information on these engineering properties is of great importance and help engineers towards efficient process and machine development Kumar et al., (2016) studied engineering properties of variety Indira Kode- 1 in the moisture range from 8.19 to 12.71 percent $(\mathrm{db})$ and observed that the length, width and thickness of Kodo increased with increase moisture content and also observed that with the increased moisture content the length breadth ratio of Kodo decreased. The size and sphericity of Kodo increased with the increase of moisture content, surface area and volume of Kodo grain increased with the increased in moisture content. The values of bulk density decreased but true density and porosity was increased with increase in moisture content. The angle of repose was increased with increase of moisture content.

\section{Materials and Methods}

The engineering properties of kodo millet with three variety of Kodo such as JNK-101, JNK364 and Niwas-1. Different properties of Kodo such as moisture content, length, width, thickness, size, sphericity, angle of repose, bulk density, true density and porosity were determined by using standard techniques. In order to determine the effect of moisture content on different physical properties of kodo and kutki, the moisture content was determined.

\section{Moisture content}

It is ratio of weight of moisture to weight of dry product. It is expressed in percentage.

Moisture content (db) \%

$=\frac{\text { weight of moisture }}{\text { weight of dry matter }} \times 1001$

\section{Length, width and thickness (LBT)}

For the measurement of seed length (L), width (W) and thickness (T), randomly 100 grains from each variety were selected for determination of $\mathrm{L}, \mathrm{W}$ and $\mathrm{T}$ by using vernier calliper with a least count of $0.01 \mathrm{~mm}$.

Size of the seeds was calculated with the following formula proposed by [2].

$\mathrm{S}_{\mathrm{Z}}=(\mathrm{L} \times \mathrm{W} \times \mathrm{T})^{1 / 3}$. 


\section{Sphericity $(\varphi)$}

Sphericity $(\varphi)$ is defined as the ratio of size of grains to the length of the grain. The sphericity is expressed in percent. [3].

$\varnothing=\frac{(L X B X T)^{1 / \sqrt{/ n}}}{L} \ldots$

\section{Bulk density $\left(\mathbf{B}_{\mathbf{d}}\right)$}

Bulk density $\left(\mathrm{B}_{\mathrm{d}}\right)$ of kodo grains was determined by taking the weight of kodo in fixed volume [4].

$\mathrm{B}_{\mathrm{d}}=\frac{W}{V}$.

\section{True density (Td)}

The true density (Td) is defined as the ratio of mass of grain to the solid volume occupied. It is determined using liquid displacement technique [5].

$\mathrm{T}_{\mathrm{d}}=\frac{M}{s} \ldots$

Porosity was calculated as ratio of the difference in the grain and bulk densities to grain density and expressed in percentage [6].

Porosity ( $(\varepsilon) \%=1-\frac{B_{d}}{T_{d d}} \ldots$ (6)

\section{Angle of repose}

A cylinder was filled up to top with sample and inverted on a plane (paper) surface. The paper was taken out gradually and cylinder was raised vertically, thus conical shape of the material was formed. Angle of repose was calculated by using the following expression [7].

$\varnothing=\tan -1 \frac{2\left(H_{a}-H_{b}\right)}{D_{b}} \ldots .(7)$

\section{Results and Discussion}

The result of physical property are shown in figure 1,2, 3 and 4 . The result of different physical properties of kodocrop with the three moisture content of $7 \%, 11 \%$ and $12.6 \%$. On dry basis are presented in the following figure and tables.

\section{Length, width and thickness}

The result shows length, width and thickness of kodo in variety JNk-101, JNk364 and Niwas-1 increased with increase in moisture content from $7 \%$ to $12.6 \%$. the length, width and thickness varied in JNK-101 from 2.38 to $2.68 \mathrm{~mm}, 1.43$ to $2.00 \mathrm{~mm}$ and 1.01 to 1.34 $\mathrm{mm}$, Similarly in JNK-364 LBT range from 2.27 to $2.72 \mathrm{~mm}, 1.34$ to $1.75 \mathrm{~mm}$ and 0.96 to $1.30 \mathrm{~mm}$ with respect to moisture content similar trend observed in in Niwas-1 LBT range from 2.44 to $2.95 \mathrm{~mm}, 1.78$ to $2.32 \mathrm{~mm}$ and 1.32 to $1.70 \mathrm{~mm}$. This happened when the moisture increased grain length, width and thickness increased due to the fact that increased upon swelling which turn in increased in LBT. As shown in figure 1-3 and required regression equation is shown in table 1.

in moisture $7 \%$ to $12.6 \%$ the size of JNK-101 varied from 1.49 to $1.91 \mathrm{~mm}$ where in variety JNK-364 the size varied from 1.43 to $1.82 \mathrm{~mm}$ and similarly in Niwas-1 the size varied from 1.76 to $2.24 \mathrm{~mm}$. The result shows that the moisture content increased with increase in size.

\section{Sphericity}

The sphericity of kodo increases with variety JNK-101 increase from 0.63 to $0.72(\mathrm{~mm})$ as the moisture content increased from 7.10 to $12.6 \%$ (db). Similarly in JNK-364 and Niwas1 the sphericity increased from 0.61 to 0.67 and 0.72 to $0.76(\mathrm{~mm})$. There is little variation at $11 \%$ moisture content in Niwas- 1 due to the 
effect of variety and moisture content. The relationship between spherecity and moisture in following equations (Fig. 4-6).

\section{Size}

The size of kodo with three variety JNK-101, JNk-364 and Niwas-1 increased with increase
For Kodo JNK-101, y $=0.045 \mathrm{x}+0.59$, $\mathrm{R}^{2}=0.964$

For Kodo JNK-364, y = 0.03x +0.583 , $\mathrm{R}^{2}=0.964$

For Kodo Niwas- $1, \mathrm{y}=0.03 \mathrm{x}+0.583$, $\mathrm{R}^{2}=0.964$

Table.1 Correlation between length, width and thickness

\begin{tabular}{|c|c|c|c|}
\hline Parameters & Kodo JNK-101 & Kodo JNK-364 & Kodoniwas -1 \\
\hline Length & $0.15 \mathrm{x}+2.266$ & $0.175 \mathrm{x}+2.23$ & $0.255 \mathrm{x}+2.19$ \\
& $\mathrm{R}^{2}=0.848$ & $\mathrm{R}^{2}=0.892$ & $\mathrm{R}^{2}=0.998$ \\
\hline Width & $0.285 \mathrm{x}+1.186$ & $0.205 \mathrm{x}+1.176$ & $0.27 \mathrm{x}+1.366$ \\
& $\mathrm{R}^{2}=0.939$ & $\mathrm{R}^{2}=0.889$ & $\mathrm{R}^{2}=0.541$ \\
\hline Thickness & $0.165 \mathrm{x}+0.876$ & $0.17 \mathrm{x}+0.813$ & $0.19 \mathrm{x}+1.086$ \\
& $\mathrm{R}^{2}=0.900$ & $\mathrm{R}^{2}=0.946$ & $\mathrm{R}^{2}=0.865$ \\
\hline
\end{tabular}

Table.2 physical property of kodo millet

\begin{tabular}{|c|c|c|c|c|c|}
\hline $\begin{array}{c}\text { Moisture } \\
\text { content }\end{array}$ & variety & Bulk density & True density & Porosity & $\begin{array}{c}\text { Angle of } \\
\text { repose }\end{array}$ \\
\hline $\mathbf{7 . 2 \%}$ & Kodo JNK 101 & 676.67 & 1202.67 & 43.74 & 25.28 \\
\hline & Kodo JNK 364 & 674.33 & 1201.33 & 43.87 & 25.26 \\
\hline & Kodo NIwas-1 & 671.67 & 1203.00 & 44.17 & 25.39 \\
\hline $\mathbf{1 1 \%}$ & Kodo JNK 101 & 677.00 & 1228.00 & 44.87 & 25.90 \\
\hline & Kodo JNK 364 & 678.50 & 1220.50 & 44.41 & 25.83 \\
\hline & Kodo NIwas-1 & 681.50 & 1224.50 & 44.34 & 25.89 \\
\hline $\mathbf{1 2 . 6 \%}$ & Kodo JNK 101 & 681.00 & 1228.50 & 44.57 & 26.07 \\
\hline & Kodo JNK 364 & 684.33 & 1228.80 & 44.31 & 26.04 \\
\hline & Kodo NIwas-1 & 686.07 & 1227.90 & 44.13 & 26.07 \\
\hline
\end{tabular}

Table. 3 correlation between Bulk density, True density and porosity

\begin{tabular}{|c|c|c|c|}
\hline Parameters & Kodo JNK-101 & Kodo JNK-364 & Kodoniwas -1 \\
\hline Bulk & $2.165 \mathrm{x}+673.8$ & $3.335 \mathrm{x}+671.2$ & $\mathrm{y}=7.2 \mathrm{x}+665.3$ \\
density & $\mathrm{R}^{2}=0.806$ & $\mathrm{R}^{2}=0.979$ & $\mathrm{R}^{2}=0.957$ \\
\hline True & $12.91 \mathrm{x}+1193$. & $13.73 \mathrm{x}+1189$. & $12.45 \mathrm{x}+1193$. \\
density & $\mathrm{R}^{2}=0.764$ & $\mathrm{R}^{2}=0.950$ & $\mathrm{R}^{2}=0.850$ \\
\hline Porosity & $0.415 \mathrm{x}+43.56$ & $0.22 \mathrm{x}+43.75$ & $0.02 \mathrm{x}+44.25$ \\
& $\mathrm{R}^{2}=0.502$ & $\mathrm{R}^{2}=0.586$ & $\mathrm{R}^{2}=0.032$ \\
\hline
\end{tabular}


Fig.1 Effect of moisture content on Length, width and thickness of Kodo JNk-101

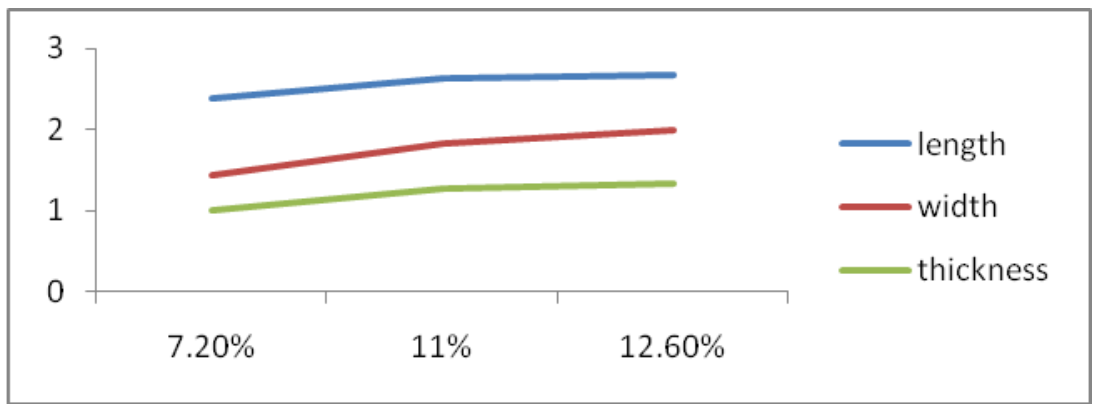

Fig.2 Effect of moisture content on Length, width and thickness of Kodo JNk-364

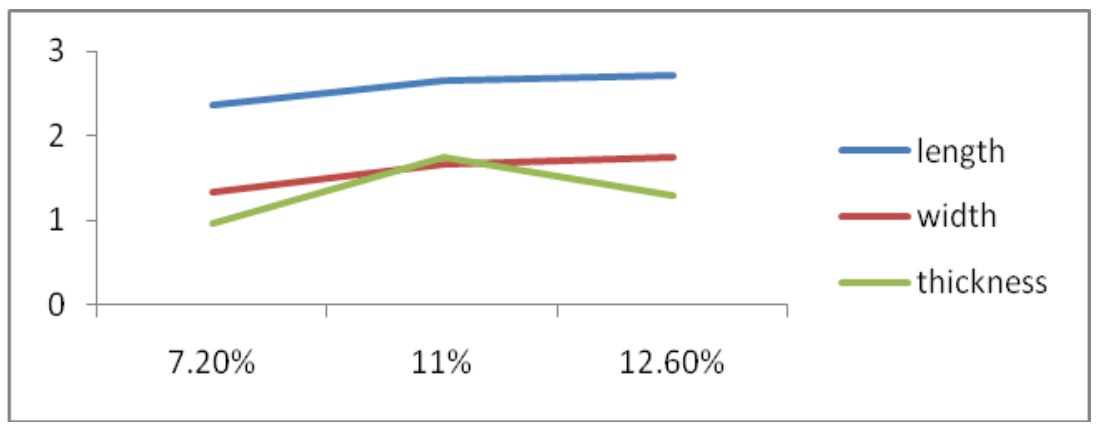

Fig.3 Effect of moisture content on Length, width and thickness of Kodo Niwas-1

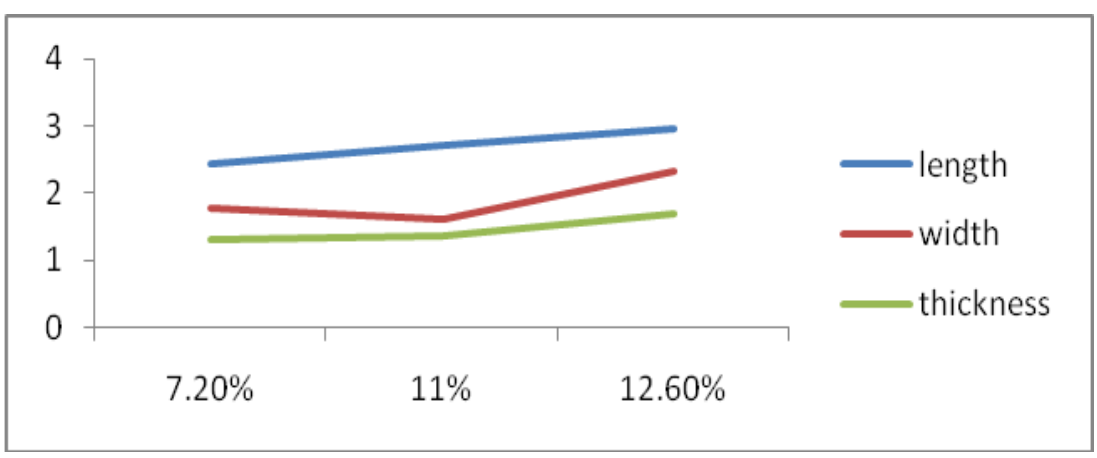

Fig.4 Effect of moisture content on sphericity of Kodo JNk-101

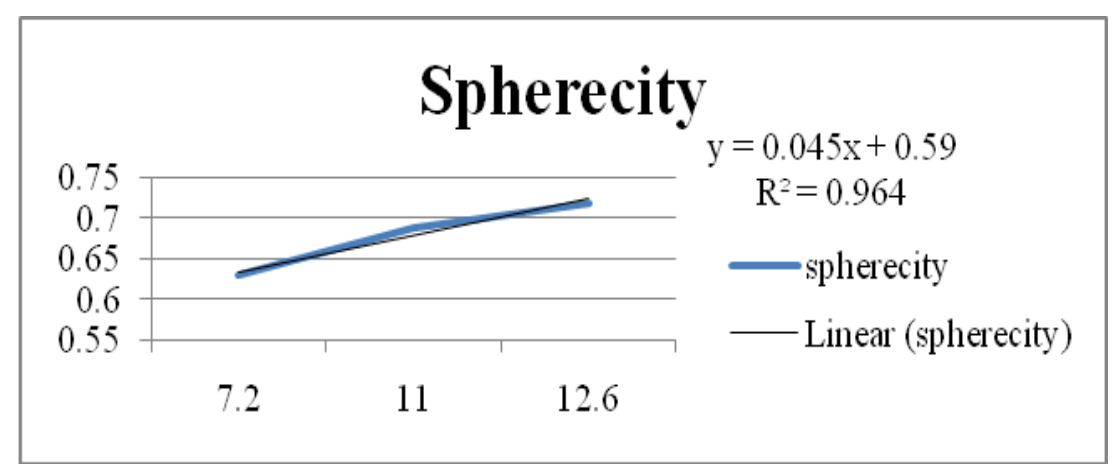


Fig.5 Effect of moisture content on sphericity of Kodo JNk-364

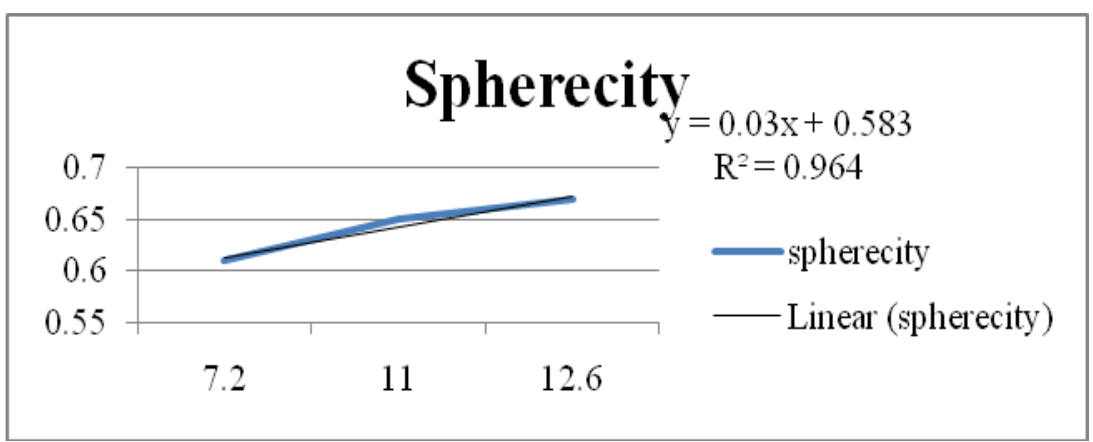

Fig.6 Effect of moisture content on sphericity of Kodo Niwas-1

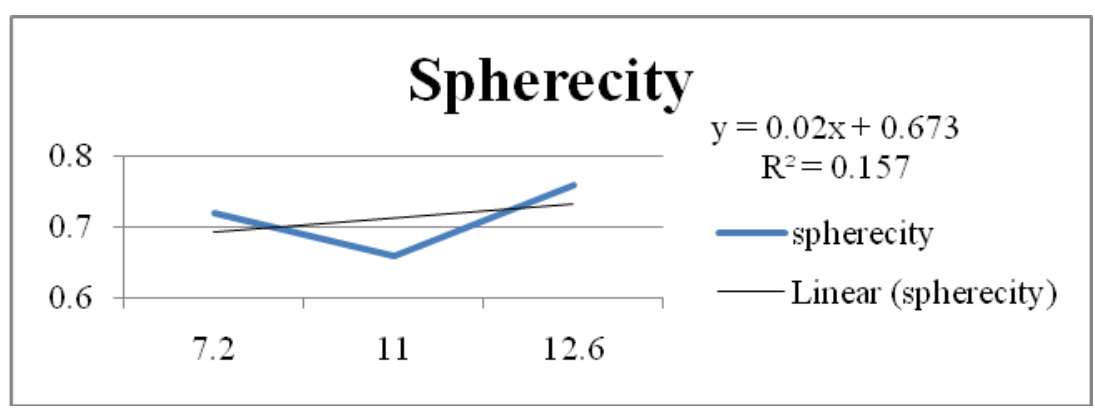

Fig.7 Effect of moisture content on angle of repose of Kodo JNk-101

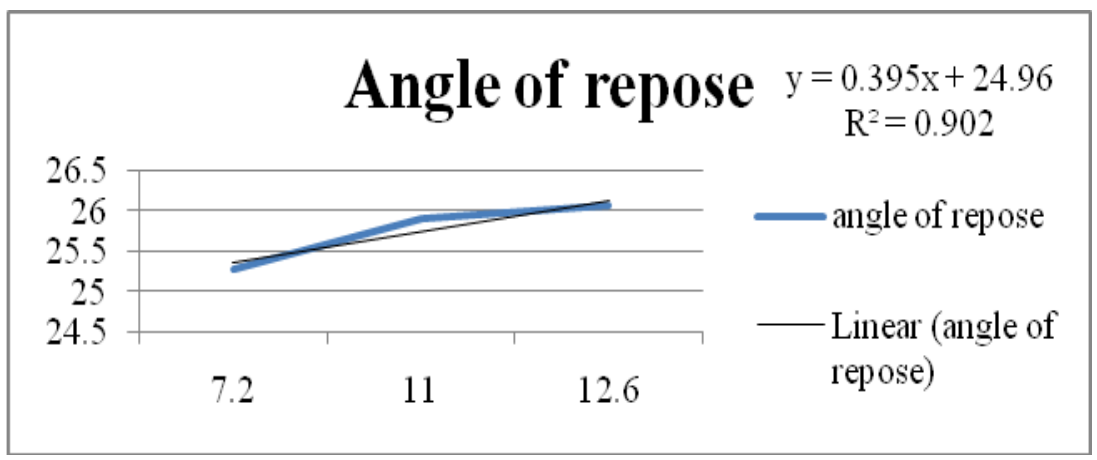

Fig.8 Effect of moisture content on angle of repose of Kodo JNK-364

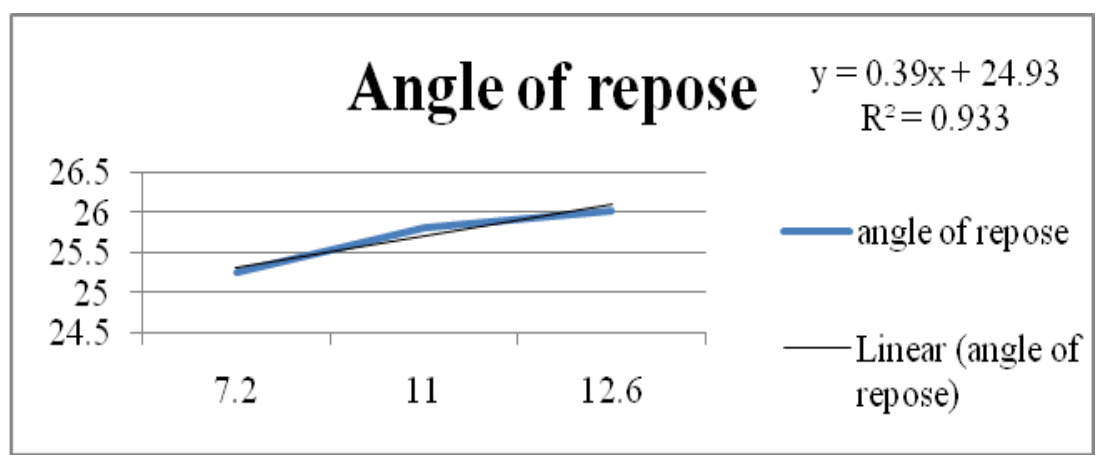


Fig.9 Effect of moisture content on angle of repose of Kodo Niwas-1

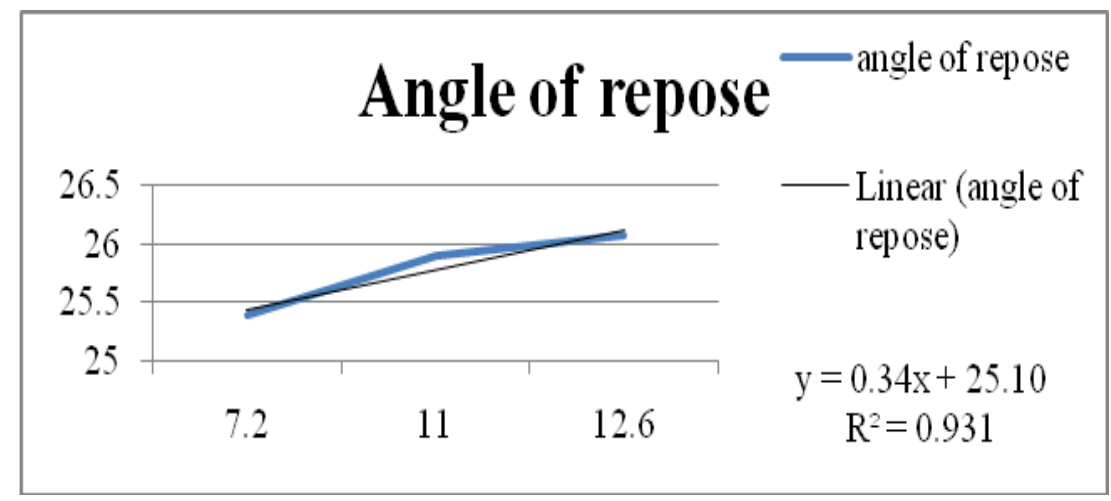

\section{Bulk density, True density and Porosity}

The bulk density, true density and porosity for kodo millet obtained at three different moisture content ranging from $7 \%$ to $12.6 \%$ $(\mathrm{db})$. The bulk density, true density and porosity increased in JNK-101from 676.67 to $681 \mathrm{~kg} / \mathrm{m} 2,1201.67$ to $1228.50 \mathrm{~kg} / \mathrm{m} 2$ and 43.74 to $44.57 \%$. Similarly in variety JNK364 the bulk density, true density and porosity increased with respect to moisture content from 674.33 to $684.33 \mathrm{~kg} / \mathrm{m} 2,1201.33$ to $1228.80 \mathrm{~kg} / \mathrm{cm} 2$ and 43.87 to $44.31 \%$. this trend also followed in Niwas-1 the bulk density, true density and porosity varied from 671.67 to $686.07 \mathrm{~kg} / \mathrm{cm} 2,1203$ to 1227.90 $\mathrm{kg} / \mathrm{cm} 2$ and 44.17 to $44.13 \%$ respectively. The equation is shown as following.

\section{Angle of repose}

The angle of repose at different moisture content range from 7 to $12.6 \%(\mathrm{db})$ increased with increase in moisture content shown in table 2 and figure 7. The angle of repose increased in JNK-101 ranged from 25.28 to 26.07 where in variety JNK-364 the angle of repose 25.26 to 26.04 and in Niwas-1angle of repose varied from 25.39 to 26.07 . The relationship between angle of repose and moisture content as shown in figure 7-9.
It was observed that the length, width and thickness of kodowith all three variety JNK101, JNK-364 and Niwas -1 increased with increasing moisture content. Also observed that the size, sphericity increased as the moisture content increases. The value of bulk density, true density and porosity was also increased as the moisture content increases. The angle of repose with all three variety increases with increase in moisture content.

\section{References}

Hadimani, N.A., and Malleshi, N.G., 1993, Studies on milling, Physico-chemical properties, nutrient composition and dietary fibre content of millets. J. Food Sci. Tech., 30: 45-52.

Itagi, S., 2003, Development and evaluation of millet based composite food for type II diabetics. Ph. D., Thesis, University of Agricultural Sciences, Dharwar.

Kulkarni, L.R., Naik, R.K. and Katarki, P.A, 1992, Chemical composition of minor millets. Karnataka J. Agric. Sci., 5(3): 255-258.

Mohsenin, N.N. 1986. Physical Properties of Plant and Animal Materials, 2nd edition. Gordon and Breach Science Publishers, New York

www.indiastate.com, 2015. 


\section{How to cite this article:}

Shalini Chaturvedi, Atul Kumar Shrivastava, Ganesh Kumar Koutu, Shiv Ramakrishnan and Sanjay Singh. 2019. Study of Physical Property of Kodo (Paspalum scrobiculatum L.) Millet. Int.J.Curr.Microbiol.App.Sci. 8(12): 1503-1510. doi: https://doi.org/10.20546/ijcmas.2019.812.180 